
REVISTA ARA Nº 3 . PRIMAVERA+VERÃO, 2017 • GRUPO MUSEU/PATRIMÔNIO FAU-USP

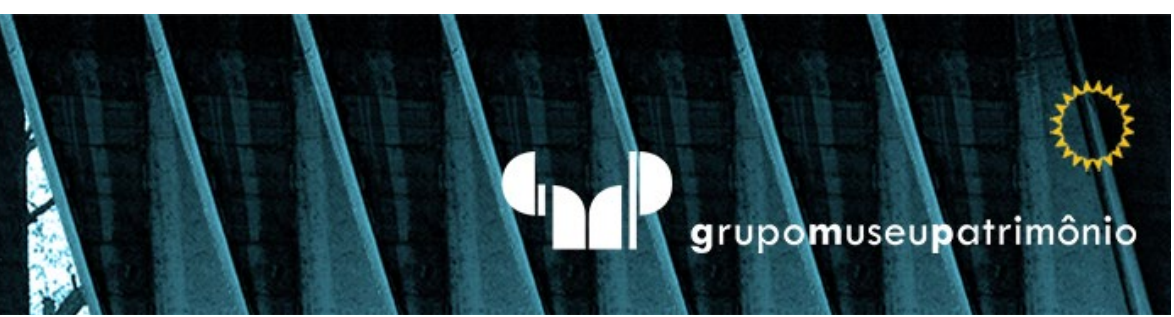

Editorial

\section{A difícil tarefa de ver}

Luz, iluminação, sombras, reflexos, cor, todos esses objetos da pesquisa não são inteiramente seres reais: como os fantasmas, só têm existência visual. Não estão, mesmo, senão no limiar da visão profana, e comumente não são vistos. O olhar do pintor pergunta-lhes como é que eles se arranjam para fazer que haja subitamente alguma coisa.

O olho e o espírito, Merleau Ponty

rte coagula-se em um algo que "está posto diante" de um outro, e que
tem sido especialmente destacado dentre os produtos da humanidade. É, no entanto, resultado de inúmeras circunstâncias: as técnicas, as matérias, as crenças (mágicas, religiosas, ilustradas), o trabalho, o valor de uso e o valor de troca - todos em movência histórica. Vista pelo presente moderno, em um primeiro momento a arte do passado tendeu a 
ser compreendida como coisa extraordinária, livre das injunções, ou pelo menos a elas não submetida substancialmente - um domínio próprio. Esse filtro da autonomia estética acionou para a arte novas possibilidades. Na modernidade e sua auto-consciência histórica, a arte pretendeu-se independente em sua radical objetividade e vislumbrou contestar e transformar o mundo desespiritualizado e aplainado da mercadoria. Tamanha potência social e crítica encontrava no século XX o seu antípoda: o valor econômico desses objetos de arte, paradoxalmente apoiado em sua excepcionalidade e vocação para a fetichização.

Iniciou-se então uma luta para ultrapassar essa dupla determinação da arte moderna como objeto aurático (a Instituição) e objeto econômico (o Mercado). Essa luta ampliou tanto as formas artísticas quanto a concordância do que seria Arte, e também a sua relação com a sociedade. Esse descoagulamento atingiu não apenas o próprio objeto artístico - seu universo sensível -, mas também o autor, a recepção, a crítica - ou seja, a constelação que a envolve com o mundo social. Tais papéis, em diferentes maneiras, se tensionaram e sobrepuseram, tornando o limite que os separa de difícil delineamento. Mais que isso, em muitos casos esse torvelinho da relação entre sujeito-objeto, entendimento e sensibilidade, torna-se o próprio mote do trabalho artístico.

A proposta para o número três da Revista ARA é o (In)visível. Ainda que com algumas claras referências ao debate sobre a arte moderna e sua reflexão crítica, esse tema se apresentou de maneira intransitiva. Isso porque esse jogo poderia incluir toda a gradação do que se considera hoje como a produção artística. E, principalmente, sua relação com a sociedade da "nova intransparência", como descreveu Juergen Habermas (1987) o divórcio contemporâneo entre as utopias e a história, outrora unificadas pela Razão. O jogo (In)visivel na arte vai além das questões imanentes da obra, avança para a sua institucionalidade, sua recepção de massa, suas autoria e originalidade, a simultaneidade entre obra e pensamento, positividade e negatividade. Esse jogo artístico se combina criticamente com a cegueira da 
sociedade saturada, a explosão de novas subjetividades, a busca por visibilidade, a dominação e opressão atualizadas em um mundo que tudo se põe à mostra - ao mesmo tempo em que tudo se torna incompreensível, indeterminado, opaco, reflexo.

A necessidade de apreensão de uma realidade cada dia mais complexa exige novas formas de arte e expressão. Mas essa diversidade deve ter em seu horizonte a ampliação de nossa capacidade de entender, e não de simplesmente espelhar acriticamente o que Bauman resumiu na "liquefação" do mundo social e individual. Para tanto, só nos resta entranhar o real e suas formas, e de sua própria energia descobrir novas possibilidades.

A Revista ARA se abriu, desde o seu início, para essa profusão de experiências, buscando receber contribuições de formato o mais variado. Essa abrangência resultou, no número que agora se apresenta, em uma generosa participação que indica a compreensão de seus propósitos por parte de um público cada vez mais amplo. O tema anunciado instigou uma série matizada de obras que reforçam a problemática do estatuto do objeto artístico nos dias de hoje. Mas algo que deve ser destacado é o fato de que a forma desses estudos não é apenas variada mas ela própria muitas vezes indefinida segundo padrões editoriais estritos. A tarefa editorial consistiu em aproximar as contribuições sem pretender sistematizá-las ou enquadrá-las em formatos pré-determinados, seguindo e procurando organizar a estrutura complexa que se insinuava no conjunto.

Esperamos que a leitura dos trabalhos se desdobre pelo diálogo sugerido, ampliando o debate. Este número consolida a proposta editorial da Revista, de ser uma plataforma de exibição e discussão da produção contemporânea de arte, sensível às transformações decisivas das formas de expressão e ação.

Luiz Recaman

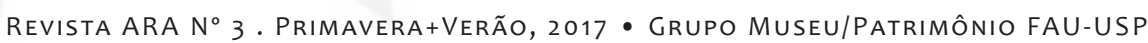

